\title{
A lost Chinese inscribed stone, some Old Hungarian script, two notable copies of Angelo Rocca's Bibliotheca Apostolica Vaticana (1591), and an addition to John Donne's library
}

On 18 September 1709 the Oxford antiquary Thomas Hearne noted in his diary:

In 1674. was dug up in the Grounds of Sir Thomas Spencer at Yarnton near Oxford a Stone with Chinese Characters. I have seen a Copy of them in a loose Piece of Paper in a Book in Queen's Library, (viz. Bibliotheca Vaticana by Rocco) C. n. $26 .{ }^{1}$

An engraving of the stone and inscription to which Hearne refers was published by Robert Plot in his Natural History of Oxford-Shire in 1677, accompanied by Plot's own conjectures about the inscription, which of course no Western scholar could convincingly decipher at this date. Plot's discussion was, however, impressive given the limitations of his resources, and he conjectured that it was a seal stone "contain[ing] only the name, and perhaps the office, or other title of some person of Quality." He described the stone as of "an odd kind of texture, and colour too, not unlike (to sight) to some sort of cheese, exactly of the figure and bigness as engraven in the Table." The stone itself has long since disappeared, and Plot, although he too mentioned the Spencer provenance of the artefact ("dug up in the garden, and now in the possession of the Right Worshipful Sir Thomas Spencer Baronet"), did not provide the date of its discovery, and the inclusion of this detail by Hearne, who knew Plot's book well, suggests that the manuscript insert Hearne saw was not derived from, and may rather have been the source for, Plot's published account. $^{2}$

$<$ insert illustration $1>$

Plot's Chinese stone, from The Natural History of Oxford-Shire (1677). New College, BT1.7.2. By permission of the Warden and Scholars of New College, Oxford.

Plot's Chinese stone was genuine, and has some claim to be the earliest discussed Chinese artefact of its kind in English scholarship. For the characters reproduced by Plot and engraved for him by the university chalcographus, Michael Burghers, are legible and genuine, albeit they are not, as one would have expected for a stamp, reversed, and are poorly formed. On the “front” face they read 保 (bao, literally “safeguarding”) 泗 (Si, a river in the Shandong province) 記 (ji, usually “record,” here perhaps “stamp” or “mark”). On the “top” we can see, again badly drawn, but reading the characters as vertical columns seen side on, right column first, 西 $x i$ (“west”), 河 (he, “river”), 郡 jun (“prefecture”), 記 ji (“record," here again perhaps “stamp” or “mark”). 西河郡 is an old place-name, “Xihe [i.e. West River] County,” thus “Xihe County record/stamp." This is therefore not, as Plot supposed, a personal seal. The only modern discussion has conjectured that it is rather a book stamp featuring Tang dynasty language but in an early Qing "antiquarianizing” imitation. ${ }^{3}$ This interpretation has its problems, however, not least the want of securely identified comparanda, and the difficulty of translating 記 $j i$ in this specific context as (literary) "account" as opposed to the more obvious and materially

I am most grateful to the librarians of Lincoln and Queen's Colleges, Oxford, for their unfailing courtesy in facilitating my examination of the books in their care.

${ }^{1}$ Hearne, Remarks and Collections, 1: 263 = Bodleian, MS Hearne's Diaries 21, p. 180.

2 Plot, Natural History of Oxford-Shire, 356-57. The passage is unaltered in the second edition of 1705 (364), except that "now in the possession" has been changed to "then in the Possession."

${ }^{3}$ Hammond and Xiao-Hui, "Sir Thomas Spencer's Chinese Seal." 
appropriate "record” or “mark." A better suggestion is that 保泗 “Bao Si” was the name of a shop or a trading house, and 记 $j i$ is closer to "mark," hence a shop stamp. ${ }^{4}$ Presumably this stamp was picked up by a merchant as a curiosity in the Far East and acquired by one of the Spencer family, or just lost there by an unknown visitor. ${ }^{5}$ As noted, the orientation of the characters is wrong for a seal, although a decade later Burghers would be called on to engrave more Chinese, this time much more convincingly, oriented correctly, and from hand-written texts rather than a cuboidal engraved object. ${ }^{6}$ Burghers, however, may only have encountered the stone through an intermediary one-to-one scale drawing, potentially the one seen by Hearne, and he must then have reversed the characters through the mirror-image process of engraving, ironically restoring them to their "correct" orientation.

The book Hearne saw is still in the library of Queen's College, and indeed boasts several additions, both manuscript and printed, to be identified below. ${ }^{7}$ Unfortunately the "loose Piece" seen by Hearne is no longer present. There is no reason to doubt his account, however, for the text itself contains lengthy discussions of various outlandish alphabets, and the other additions to this copy are all of this type. A piece of manuscript bearing a Chinese inscription is a natural addition to this volume, which was evidently used at some point in its early history as a kind of container for such materials. Queen's College library was also a tourist attraction in the period for its copy of another book of this kind, Teseo Ambrogio's Introductio ad Chaldaicam linguam, Syriacam, atque Armenicam, et decem alias linguas (Pavia, 1539), which features a woodcut of an unknown magical script popularly known as the "Devil's Hand." Charles II and his queen came to see it in 1663 , for instance. ${ }^{8}$ But it contains no inserts.

The Bibliotheca Apostolica Vaticana of Angelo Rocca is a celebration of the Vatican Library and a thesaurus of the scripts and alphabets with which the pillars of that library were adorned, with appendices on the history of languages and of libraries themselves. It was, in short, the most comprehensive text in library science of its day, and is often paired with a similar work in the vernacular, also featuring the Vatican scripts, Mutio Pansa's Della Libraria Vaticana (Rome, 1590). ${ }^{9}$ The Bibliotheca's author, the churchman, scholar, "right hand" of Sixtus V, and founder of the Roman library that still bears his name, Angelo Rocca (1545-1620), had been the head of the Vatican printing office since 1585, and thus had a particular interest in scripts and their varieties.

\footnotetext{
${ }^{4}$ My profound thanks to Mei Xin Wang of the British Museum for the suggestion of a trading house stamp, and to Helen Wang of the same institution for facilitating this discussion. I am also grateful to David Helliwell for help with this inscription.

${ }^{5}$ Spencer's grandfather, Sir William of Yarnton, died in 1609, which seems too early a date for such an acquisition. The next of the Spencers, Sir Thomas, died in 1622, and it was he who constructed the house as it was in his grandson's time. His son, Sir William (1608-1657), was knighted in 1629 in Merton, and significantly renovated the church at Yarnton, although he subsequently lived mainly elsewhere. The stone may have come in the time of Thomas or William. An added complication is that the house at Yarnton was used as a Royalist hospital in the Civil War. See [Adcock], The Spencers at Yarnton, where the stone is also noted (11-12).

${ }^{6}$ These comprise the engraving accompanying Thomas Hyde's "Epistola de mensuris et ponderibus Serum seu Sinensium," itself appended to the second edition of Edward Bernard's De mensuris et ponderibus antiquis libri tres (Oxford, 1688). For the construction of this text see Poole, "Letters of Shen Fuzong."

${ }^{7}$ Its current shelfmark is Z.e.126.

8 Ambrogio, Introductio, fp. 212v (shelfmark Sel.c.29), heavily damaged through overhandling. See Flatman, Poems and Songs, 146 ("that dungfork, pothook hand / That in Queens Colledge Library does stand"); Wood, Life and Times, 1: 49899; Magrath, The Queen's College, 2: 62, 278-79.

9 Bodleian, 4\% P 14 Art.Seld has been "grangerized" by its first owner, the London-based Dutch merchant and scholar Jacobus Colius Ortelianus, the nephew of the cartographer Ortelius, who acquired it in September 1597 in Rome, and extra-illustrated it with around thirty cut-outs of architectural prints, as well as a large engraving of Sixtus V. Colius has also blacked out offensive remarks on Elizabeth I (106-7). For Colius see Poole, "Late SixteenthCentury Cryptographical Treatise."
} 
He published many other works including a commentary on bells. ${ }^{10}$ The Bibliotheca Apostolica $V$ aticana was widely read by scholars as far remote as England in the century following its publication, who plundered it especially for its linguistic data. ${ }^{11}$

One other locally surviving copy, now in the library of Lincoln College, Oxford, affords us a pertinent comparison with the Queen's exemplar. It was owned first by the great philologist and chronologer J. J. Scaliger (1540-1609), then by the Dutch scholar Marcus Zuerius van Boxhorn (1612-53), the man sometimes credited with theorising an early version of the IndoEuropean hypothesis, and finally by Thomas Marshall (1621-85), Rector of Lincoln College and student of, among many other languages, Gothic and Malay. ${ }^{12}$ Marshall may have been interested in the Chinese stone of Yarnton too, as in the New Year of 1677 he noted in his diary, in his usual polyglot encoding, "Master Plot visited about the Chinese inscription," rather suggestive given the publication of Plot's book later that year. ${ }^{13}$ Now, Marshall's copy of the Bibliotheca too boasts manuscript additions, namely a transcript by Marshall of a well-known letter by the Archbishop of Armagh, James Ussher (1581-1656), on Gothic, and an ancient "Hunnic" alphabet provided by "J N Harsanyi Hungarus et Consiliarius Ducis Brandenburg," i.e. the Hungarian orientalist and counsellor, from 1667, to the Elector Friedrich Wilhelm of Brandenburg, Jakab Harsányi Nagy (Latin: Jacobus Nagy de Harsani, 1615-before 1684). ${ }^{14}$

$<$ insert illustration 2>

Lincoln College, Senior Library, E.9.2, inscription in back end-papers. By permission of the Rector and Fellows of Lincoln College, Oxford.

Marshall had an attested interest in the relation between early European scripts, specifically in the context of the early transmission of the Gospels, and he would have been very

\footnotetext{
${ }^{10}$ For Rocca, his book, and the Vatican Library alphabets and their sources, see Serrai et al., Storia della bibliografia, 5 : 146-86; Serrai, Angelo Rocca, esp. 28-42; Alonso, “Angelo Rocca”; Nelles, "Vatican Library Alphabets"; and on the library more generally see Grafton, ed., Rome Reborn.

${ }^{11}$ E.g. Edward Brerewood's evergreen Enquiries touching the Diversity of Languages and Religions through the Cheife Parts of the World (1614, four editions to 1674) frequently cited "Roccha." For a sighting of the library and its decorations by a contemporary English traveller, see John Evelyn's diary under 18 January 1645: "The Walles and roofe are painted ... [with] Emblemes, Figurs, Diagramms . . of which there are now whole Volumes extant," possibly a reference to Rocca's book.

${ }^{12}$ It is now Lincoln College, Senior Library, E.9.2, in a typical Low Countries vellum binding, with stacked provenance inscriptions commencing in an early hand "olim Josephi Scaligeri," then with Boxhorn's inscription "nunc Marci Zuerii Boxhornii” below, followed by "deinde Tho: Mareschalli," itself charmingly followed in Marshall's hand by a prospective and uncompleted "Et postea." There are various earlier markings in the front endpapers including the Dutch price of $3 f l .3 s t$., and signs of a fourth owner who only got as far as "Sum Hen[...]" in pencil. There are several other annotations throughout the book in a number of hands, chiefly those of Boxhorn and Marshall. A tiny comment in Latin in a Low Countries italic above the Harsányi material, to be discussed next, notes that the word zanclo means falx ("sickle") in "lingua secila." We might have suspected this to be a reference to the Székeli too, but the attribution to "Thucid. p. 414" demonstrates that this is simply a reference to Thucydides 6.4.5, where the city name of "Zancle" (i.e. ancient Messina) is explained as deriving from its sickle shape, "and the Sicilians call a sickle zanclon." My thanks to John Considine for correspondence on this inscription. Lincoln College also holds a copy of the first Icelandic bible ("Gudbrands Biblia”) from Scaliger's library (L.4.11), a gift to Scaliger from his pupil Geverhart Elmenhorst. Nearing death, Scaliger distributed some of his printed books to a handful of friends, and the rest went to auction (Scaliger, Epistolae, 835).

13 MS Marshall Or. 113, fol. 73v, under 2 January 1677, "D. פלוט [written in cursive Hebrew] visitat de Sinicâ inscriptione." This manuscript is navigable, if still not easily legible ("sed lectu difficilis," its first cataloguer confessed [Bernard, gen. ed., Catalogi, no. 8675]), once it is realised that the years are expressed in what are now termed Eastern Arabic numbers, the months in Latin transliterated (with the Persian triple-dotted " $p$ " added for “April”!) into Arabic, and the days in standard Byzantine forms of Greek numbers adopted for printed Greek in the West too.

${ }^{14}$ For the Ussher letter, of 13 July 1651, to Franciscus Junius, see Van Romburgh, ed., For my worthy freind $M r$. Franciscus Junius, 802-10; Marshall states that he copied the autograph in 1657.
} 
interested in the relation, or otherwise, between such scripts and this Hungarian example. ${ }^{15}$ But how Marshall acquired this very unusual inscription is problematic. Harsányi indeed had visited Britain, but back in the 1640s, long before Marshall could have acquired this book, and the two cities in which he stayed were Cambridge and Edinburgh, there being no record of an Oxford stop at this time. Harsányi, whose academic peregrination included enrolment at Franeker and Leiden universities, had returned to his homeland by 1643, long before Marshall moved to the Low Countries, where he lived in Rotterdam and then Dordrecht between 1648 and $1672 .{ }^{16}$ So the two men probably could not have met there either. The simplest hypothesis is that Marshall acquired this book at the posthumous auction of Boxhorn's books in Leiden in $1654,{ }^{17}$ and copied this inscription into it some time after 1667 from an intermediary source. The more interesting possibility is that Harsányi himself paid a late and hitherto unrecorded visit to Britain, and to Oxford. Now the seventeenth-century Oxford antiquary Anthony Wood transcribed from a lost register the names of foreign visitors to the Bodleian in the period, and in his transcript we find one "Joseph Nagyan, Hungarus" recorded as a new reader on 22 September 1676. ${ }^{18}$ Hungarians were fairly rare beasts in Oxford in the period, although "Nagy" is not a rare name, and the entry is not an exact match. Notwithstanding this, did Harsányi in fact encounter Marshall in Oxford at this point, and transmit his script directly? It seems significant to me that Harsányi's modern biographer does not, as far as I can detect, report any life records confirming Harsányi's whereabouts between late 1674 and some time in 1679, and I tentatively propose that he and the "Joseph Nagyan" in the Bodleian in late 1676 are one and the same man."

Despite the patriotic aetiology, the "Harsányi" script is not "Hunnic," about which language almost nothing is known, but the much more recent Old Hungarian or Székely script, derived ultimately from Old Turkic script, and hence, despite its modern name of "rovás" ("runes"), unconnected with Germanic runes. (The Székelys were Hungarians settled in Transylvania in the period and who believed themselves to be descended from the Huns.) This script was attracting some scholarly attention by the sixteenth century, ${ }^{20}$ but remained to his frustration altogether unobtainable by the writer of the first published Hungarian grammar,

15 "Observationes de Versione Gothica," in Junius and Marshall, eds., Quatuor D.N. Jesu Christi Euangeliorum, 385-90, correctly positing the conscious debt of Ulphilas's Gothic script to Greek letter forms. Incidentally, Thomas Barlow (see below) has annotated this section in his presentation copy from Junius (Queen's College, UU.i.251).

${ }^{16}$ For Harsányi see Kármán, Seventeenth-Century Odyssey, esp. 22-45. He travelled in Britain with his countryman Pál Tarczali, whose son later managed to publish while himself visiting Oxford a Brevis dissertatio de vocatione gentium et conversione Judaorum in 1672, reissued the following year (for it see Madan, Oxford Books, nos. 2949, 2989), dedicated to, among others, Harsányi himself. It is an exceptionally rare book, but the copy in Queen's College (UU.b.1231(2)) bears a manuscript letter seeking help in obtaining a licence to print from the author to Thomas Barlow, for whom see below; and the Bodleian copy is possibly one bequeathed by Marshall himself (Mar. 148 (14)). Tarczali also approached William Sancroft (MS Tanner 33, fol. 56r). For further Hungarians in Oxford at this time see Poole, "Barlow's Books," 32, n. 61, adding now János Nadányi, Florus Hungaricus (Amsterdam, 1663), with presentation inscription to Barlow, at Queen's College, JJ.s.174.

${ }^{17}$ It is indeed listed in [Boxhorn], Catalogus variorum \& insignium librorum, sig. C2r, no. 251. Marshall evidently acquired other books from Boxhorn's library after his death; compare Lincoln College, B.2.9, a copy of Montague's $\Theta E A N \Theta P \Omega \Pi I K O Y$, seu de vita Jesu Christi Domini nostri originum ecclesiasticarum libri duo (London, 1640), itself given to Boxhorn in the year of publication by his friend the lawyer Willem Goes (1611-1686).

18 Bodleian, MS Wood E 5, p. 116. Marshall's diary (MS Marshall Or. 113) appears not to mention a meeting with any Hungarus, however, in this week (see fol. 68v).

${ }^{19}$ Kármán, Seventeenth-Century Odyssey, 176, 179.

${ }^{20}$ Most notably Johannes Telegdi, "Rudimenta priscae Hunnorum linguae," manuscript of originally 1598, surviving in a very few later manuscript copies. (A repeatedly reported printed edition of Leiden of that year is a bibliographical ghost.) Judging from the facsimiles and text of the 1909 edition by György Sebestyén of the $\mathrm{T}(\mathrm{h})$ elegdi tract made available through http://rudimenta.uw.hu/HU/thelegdi-forditasa.htm, the Harsányi alphabet does not seem to derive from Telegdi's primer, which presents a 32- rather than a 34-character script. Moreover, Telegdi's commentary explains that the letters are pronounced with an initial vowel, and glosses them thus as syllables (“A," "eb," “ecs," "ecsi,” etc.), whereas the Harsányi transliterations omit the vowel (“A," "b," "cz," "cs,” etc.). 
Albert Molnár, in 1610. ${ }^{21}$ This raises the question of how Harsányi acquired his own sample, if the script was already a rarity before his birth. Perhaps Harsányi was simply better connected at home than Molnár. One alternative possibility, remote but intriguing, is that Harsányi encountered the script abroad, specifically in Constantinople. The evidence here comes from the journal of Hans Dernschwam, a Bohemian-born scholar with epigraphic interests who in the mid sixteenth century had accompanied the Flemish diplomat (and, famously, discoverer of Crimean Gothic) Ogier Ghiselin de Busbecq on his embassage to the Ottomans. In Constantinople Dernschwam observed a peculiar inscription carved into the marble stone ("von einem marmel stain") in a waiting room for foreign diplomats and copied it into his journal, which survives. It has proved to be Székely script, and, as the inscription did not flatter the Sultan, presumably therefore used "to baffle inquisitive Turkish courtiers." 22 Now Harsányi spent most of the 1650s in Constantinople working as a diplomat too, and although this was of course a century after Busbecq and Dernschwarm, it is possible that the Székely script had remained in use there in the intervening period, albeit among a tiny community, for steganographic purposes.

The very "antiqua priscorum Hunnorum 34 Elementa" as recorded in Marshall's book were then printed by George Hickes in the preface to his celebrated collection of the grammars of older Northern languages, the Linguarum Vett. Septentrionalium Thesaurus (Oxford, 1705), with commentary so exactly mirroring the wording accompanying this inscription that one must have been the source for the other. ${ }^{23}$ Examination of both suggests strongly that the "Marshall" text is the source, with the order of the characters slightly garbled, but the phrasing of the explanation retained. ${ }^{24}$

$<$ insert illustration 3>

Detail from Hickes, Thesaurus, vol. 1, table to "Praefatio," p. viii. New College, NB.187.17. By permission of the Warden and Scholars of New College, Oxford.

Hickes says that he acquired the sample in the hand of "Joh. Harsanyi," done "ante XXV annos," from the well-known textual critic, and principal of St Edmund Hall, John Mill (1644/51707) ("cui ea accepta gratus refero"), who I propose therefore derived his (untraced) copy from this very inscription. The preface in which this comment is made was, despite the later publication year of the whole work, signed with the date of 1 January 1703, implying therefore a mid-1670s date for the Harsányi inscription, which would correspond with a derivation from

\footnotetext{
${ }^{21}$ Albertus Molnár Szenciensis, Nova Grammatica Ungarica, 23: "Siculorum vel Szekeliorum Transalpinorum literas Hunniacas, quarum meminit Stephanus Székel in suo Chronico Ungarico, nunquàm vidi, neque hominem novi, qui eas viderit." This is followed by his plea to the Transylvanian Szeculi to publish their script, if it is known. The chronicle alluded to is István Székely, Chronica ez vilagnac yeles dolgairol (Kraków, 1559).

${ }^{22}$ Dernschwam, Tagebuch, 40, 283 n. 193. The quotation is from Considine, Dictionaries in Early Modern Europe, 13940, to whom I owe this anecdote. For a study of the inscription see Babinger, "Eine neuentdeckte ungarische Kerbinschrift."

${ }^{23}$ Hickes, Linguarum Vett. Septentrionalium Thesaurus, 1: table to "Praefatio," p. VIII, no. VII, and see p. XVII, for the commentary.

${ }^{24}$ Marshall: "Hæc sunt antiqua priscorum Hunnorum 34. Elementa, quibus à dextrâ ad sinistram in scribendo, more orientalium, utebantur: hodiè characteres Romanis usurpant. J. N. Harsanyi, Hungarus \& Consiliarius Ducis Brandenburg." Hickes: "Hæc sunt antiqua priscorum Hunnorum 34 elementa, quibus ad sinistram in scribendo more orientalium utebantur, docti nonnulli me rogarunt. Illa igitur ante XXV annos Joh. Harsanyi, Hungari, manu delineata sub. tab. num. (VII) exhibenda rogantibus morem gerentes curavimus.” As for the sequences, the Marshall version attempts to follow, right-to-left, the order of the Roman alphabet, but with two subsequences omitted and then appended, corresponding to Roman i-k and then r-t. The Hickes sequence attempts the same order, right-to-left, but with more pronounced perturbation in the sequence, with interpolations running, unalphabetically, $\mathrm{j}-\mathrm{k}-\mathrm{r}$ and then $\mathrm{i}$ sz-r-ty. Because the level of deviation from the target order in the Hickes list is therefore higher than that in the Marshall list, the Hickes list represents a later point in the transmission of this sequence, directly or indirectly derived from the Marshall order.
} 
Marshall, and also lends support to my hypothesis that the "Joseph Nagyan" in the Bodleian in 1676 was indeed Harsányi.

To return to the copy in Queen's College, although now lacking its Chinese insert it is notable too for its surviving additional material — of broadly the same genre as the material added to the Lincoln copy. At the front of the book, four printed tables of syllables in various scripts with parallel Latin and German explanations have been pasted in, and these prove to have been published in 1583 in Berlin by the eccentric metallurgist, Paracelsian, printer, and sometime physician to the Elector of Brandenburg, Leonhard Thurneisser zum Thurn (1531-1595/96). These tables, best situated within alchemical and Paracelsian discourses, tend to survive in two forms: as an appendix to Thurneisser's large folio Onomasticum of the same year and place, ${ }^{25}$ or as a loose set of prints, presumably available separately. The title-sheet (not present in the Queen's copy) of the tables is headed Tabula quarundam syllabarum ... / Tafel etliche Sylben ..., and it is under that title that the separate form should be sought. In its full extent there should be seven complete sheets. These were clearly envisaged as charts, presumably to be mounted on walls, as the title sheet is printed on two separate sheets, which before the text can make sense must be cut in two across the middle, pasted together at the edges, and then the first mounted on top of the second. Loose sets are understandably rare, and I have traced only four others, one similarly incomplete one among the Selden books in the Bodleian, and three in German and Swiss libraries. $^{26}$

$<$ insert illustration 4>

The Queen's College, Old Library, Z.e.126, printed insert of Thurneisser, Tabula, "A" table. Used with the permission of the Provost and Fellows of The Queen's College.

At the back of the Queen's book, there are further inserts displaying various other alphabets, this time in manuscript, including an "Alphabetum Croaticum," an "Alphabetum Muscoviticum," notes on the origin of Greek and Latin letters, an inscription found on a tower named "Baych" from "Panormus," two "Jacobite" (i.e. Syriac) alphabets, and finally the "Aeolic" (a variant of Greek) and Cyrillic alphabets.

$<$ insert illustrations $5 \mathrm{a}, 5 \mathrm{~b}>$

The Queen's College, Old Library, Z.e.126, manuscript insert of extracts from de Bry, Alphabeta. Used with the permission of the Provost and Fellows of The Queen's College.

These have all been copied out by one as yet unidentified scribe, most likely in the early years of the next century, but his source can be confirmed. This is the Alphabeta et Characteres of the brothers Theodore and Johann Israel de Bry, an oblong book of engravings published in 1596, indeed featuring, among many other alphabets, the Greek, Cyrillic, Jacobite, Aeolian, Croatian,

\footnotetext{
25 See, e.g., the copy at Bodleian, M 1.4(1) Med. This, like the appended tables, was printed for Thurneisser by the Berlin academic printer Nikolaus Voltz. For it see Sudhoff, Bibliographia Paracelsica, no. 194 (336-40), which does not recognise the tables as a separate bibliographical entity.

${ }^{26}$ The plates appended to Bodleian, M 1.4(1) Med. demonstrate what the complete set should look like: a title page, constructed out of two sheets cut transversely, pasted together, and then stacked; then five sheets each governed by the five vowels, and a "weights and measures" sheet (ordered title-pages(s), "A," "E," "U," "weights and measures," "I," "O" in this copy). Bodleian, 4 G 59 (2) Art.Seld., contains only four of the completed sheets, being the "U," "I," the "weights and measures," and the "A" sheet, in that order. There is a complete copy in the Staatsbibliothek zu Berlin, organised: title-page (correctly assembled from the two sheets), "A," "weights and measures," "E," "U," "I," "O." A facsimile of the Berlin exemplar is available through the Digitalisierte Sammlungen database (https://digital.staatsbibliothek-berlin.de/). The Queen's sheets comprise therefore four of these seven, missing the title sheet(s), and both the "U" and the weights and measures sheets. The only other recorded copies are in Göttingen and Basel (OCLC 46261757 and 601100141). It is listed as a separate bibliographical entity in Brüning, Bibliographie der alchemistischen Literatur, no. 555. For a summary biography of the author, see the article in the Allgemeine Deutsche Biographie, 38 (1894): 226-29; a recent study is Spitzer, —und die Spree fübrt Gold (see 92 for these tables).
} 
and Muscovite alphabets in exactly the forms copied here. The scribe's notes on the evolution of the Greek alphabet from Cadmus, through Pythagoras, Simonides, Epicharmus, and Palamedes, and on the origin of the Roman alphabet, are likewise again exact transcriptions from the relevant plates in the de Bry collection, confirming it as the direct and sole source for these notes. The "Panormus" script is credited to "Fazellus," i.e. the Dominican antiquary Tommaso Fazello, in whose compendium of Sicilian historiography De rebus Siculis (1558) indeed we find the source woodcuts for this strange script ("Panormus" is the Latin name for Palermo). ${ }^{27}$ But as a plate copying these pages is also present in the De Bry collection, and as the scribe copies the De Bry superscription exactly, it must once again derive solely from that source. ${ }^{28}$ Despite Fazello's patriotic claims for the "Chaldaean" origin and antiquity of the script displayed, it is obviously of the Arabic family, and thus presumably dates from the period of the ninth- to eleventh-century Emirate of Sicily, and no earlier.

Facing the title page of the Queen's copy there are also a number of manuscript notes in Latin on the contents of the book, and on Church Councils. This hand is near-contemporary with publication, and may be that of the first owner of the book. It is plausibly an Italian hand, and not likely an English one. It is impossible to know whether the owner of this hand was responsible for mounting the inserts or not, and whether we should associate the inserter of the manuscript additions with the inserter of the printed additions. This problem becomes especially tantalizing when we turn to the next owner of this book.

This was none other than the poet and preacher John Donne (1572-1631). Donne has placed his signature on the title-page in the lower right-hand corner, and at the top of the page he has added his typical motto in praise of the contemplative life, "Per Rachel ho servito, \& non per Lea," taken from Petrarch ("for Rachel I served [you], and not for Leah," a reference to Jacob's two wives, standing respectively for the contemplative versus the active life). ${ }^{29}$ These are the usual positions for Donne's marks of ownership. Both inscriptions have been cancelled, but not so thoroughly as to render them illegible.

$<$ insert illustrations $6 \mathrm{a}, 6 \mathrm{~b}>$

The Queen's College, Old Library, Z.e.126, title-page, and detail of signature. Used with the permission of the Provost and Fellows of The Queen's College.

There is unfortunately no obvious verbal annotation in the book in Donne's hand. We might pause over some underlining-with-manicule in Rocca's prefaced biobibliography of authorities, notably under and alongside the entry for St Bonaventure, where is reported the statement of Alexander of Hales that "in Brother Bonaventure Adam seems not to have sinned" (In Fratre Bonaventura Adam pecasse non videtur), a compliment delivered as a theological paradox. One would like to think that this piece of metaphysical wit trouvé might have been appreciated by Donne. But Donne in his attested books invariably annotated in pencil, and did not use manicules. It is possible that the same hand is also responsible for an underlining on p. 87 to the statement that Moses received the Hebrew vowel pointings directly from God when on the mountain. ${ }^{30}$

\footnotetext{
${ }^{27}$ Fazello, De rebus Siculis decades duae, 166-67, or Rerum Sicularum scriptores ex recentioribus praecipui, 150-1. There was an Italian translation of 1574 too, with the like illustration.

${ }^{28}$ I have consulted Bodleian, Ashmole 565 and Douce B 643.

${ }^{29}$ It is from Petrarch, Canzone, 206.55. For Donne's known books see Keynes, A Bibliography of Dr. John Donne, 258279 (Appendix IV), and, for a bibliography of updates to Keynes, Peter Beal's introduction to Donne in the database CELM (http://www.celm-ms.org.uk/introductions/DonneJohn.html). It is the second such book to have been identified in Queen's: that college's copy of Marcobruni, Raccolta di lettere (1595) is also from Donne's library. ${ }^{30}$ Donne himself appears to have been comfortable with the view that the vowel-points were post-biblical. See Essayes in Divinity, 49.
} 
Donne does not appear to have cited the Bibliotheca Apostolica Vaticana in his published writings, but he did refer to Rocca on bells, a text mentioned earlier, in his Devotions of $1624 .{ }^{31}$ Isaac Walton said that "at his entrance into the nineteenth year of his age" (i.e. c. 1591), Donne "begun to survey the Body of Divinity, as it is controverted betwixt the Reformed and the Roman Church"; this would chime nicely with the date of publication of the Bibliotheca Apostolica Vaticana. ${ }^{32}$ But the form of Donne's signature has been judged "late," perhaps from after 1612, and this reinforces the sense that the cluster of "alphabet" activity identified earlier in this note predates Donne's acquisition of this book. ${ }^{33}$

Now Donne was abroad from 1619 to 1620, serving as chaplain to Viscount Doncaster, who had been sent on a diplomatic mission to the Holy Roman Emperor, at that point kindling what would become the Thirty Years War. This mission took Donne from Calais through the Low Countries into the German lands, where his diplomatic train visited many cities including Heidelberg, Munich, and Frankfurt. Now, given the rarity of the Thurneisser printed inserts it is reasonable to think that these were most likely acquired in Germany. Might Donne have acquired the book, already sporting its inserts, abroad? Unfortunately the binding evidence does not support this hypothesis, as the style (calf, rebacked, but with original boards featuring oval centrepieces with small horizontal bars) is most likely English, specifically a Cambridge style of the late sixteenth century. ${ }^{34}$ Unless this is a rare example of a recycled binding, we shall have to concede that this book arrived in England long before Donne went to Germany. In that case, it was either imported immediately, or it had one early continental owner before it came to England, depending on where one thinks the initial annotator was at work. If it was not an immediate import, it was rebound rather than bound in England, probably in Cambridge, but only much later acquired by Donne. It may be that Donne, like Thomas Marshall after him, decided to use the book as a wallet for other loose examples of outlandish scripts, placing in it a curiosity he had picked up while in the German lands, and possibly someone else's transcriptions from the De Bry album; or it may be that an earlier owner did all or some of this.

The final owner before the book came to its current location was the prominent seventeenth-century Oxonian Thomas Barlow, Keeper of Bodley's Library between 1652 and 1660, Provost of Queen's College from 1658, Lady Margaret Professor of Divinity from 1660, and finally Bishop of Lincoln from 1675 until his death in 1691. He bequeathed his considerable library to the Bodleian, with unwanted duplicates going to his own college, and it is for that reason that several hundred of Barlow's books are to be found in Queen's today. ${ }^{35}$ Barlow acquired this book in Oxford in 1638, as his title-page inscription attests. As Donne's books were dispersed shortly after his death in $1631,{ }^{36}$ this is a comparatively tight window for transmission to Barlow, but it points to yet another owner between the two men, the person who carried to the book to Oxford, if this was not just a bookseller operating between the two cities. As Barlow's custom often was with his books, he has further added to the title-page his

\footnotetext{
${ }^{31}$ Devotions upon Emergent Occasions, 391-92.

32 Walton, The Life of John Donne, 10.

${ }^{33} \mathrm{My}$ thanks to Hugh Adlington for confirming that the current volume has not hitherto been identified as a Donne book, and for advising me on the dating of Donne's ownership marks. In support of his opinion, in a survey of a dozen or so approximately datable Donne autographs on books the most palaeographically similar signature I have observed is affixed to Arnisaeus, De subjectione et exemptione clericorum (1612), at Bodleian, 4o A 9 Jur.Seld.

${ }^{34}$ The centrepiece is so worn that this binding must have been executed late in its life. David Pearson directs me to the similar but not identical style applied to Christ's, Cambridge (D.3.3, Massaeus, Chronicorum . . libri viginti (Antwerp, 1540), probably bound in the 1590s); Magdalen College, R.6.14, a collection of botanical works printed in the 1570 s, is typologically similar. For the outside chance that the binding is continental—which would of course reactivate the possibility of Donne acquiring it abroad-Pearson points to the German 1580s example illustrated in Nixon, Broxbourne Library, no. 46/p. 95, which is again certainly typologically similar.

35 Poole, "Barlow's Books."

${ }^{36}$ The bulk of his library may have been acquired and sold piecemeal by a Duck Lane bookseller, to judge from a later purchaser's inscription dated 13 December 1633 on Donne's copy of Paracelsus, of which only the title-page now survives (Keynes, Bibliography, 273 (L135); Bald, John Donne, 532).
} 


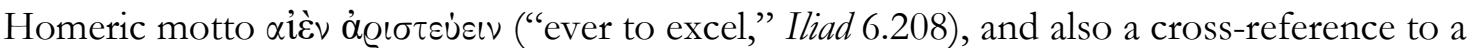
similar publication, namely Guillaume Postel's 1538 Paris collection of scripts, the Linguarum duodecim characteribus differentium alphabetum, introductio, ac legendi modus, even adding its shelfmark in the Bodleian, where it still is today. ${ }^{37}$ Given Barlow's unbroken ownership of the book until his death, we must also assume that either he, or some very early reader in Queen's, was responsible for inserting the now lost Chinese paper, but it seems less likely that he was responsible for the earlier inserts, given their shared sixteenth-century textual origins.

Barlow's annotations are few but of clear intellectual purpose. For when he encountered the passage (p. 89) in which Rocca concurred with a well-known statement in the church father Jerome on the origin of the Hebrew letters, Barlow sternly contradicted both the father and his modern follower. Jerome had claimed that the most ancient Hebrew letters were those still in use among the Samaritans in his time, and that the received Hebrew letters were in fact a later invention dating from after the capture of Jerusalem and the rebuilding of the temple under Zerubbabel. For Barlow this "Second Temple" origin for the received Hebrew script was intolerable, and on the next leaf (p. 91) we find a further annotation on the topic, citing the Lutheran Hebraist Wilhelm Schickard's insistence that the received Hebrew script is very ancient, much older than the Samaritan script. ${ }^{38}$ This was a bone chewed over by many a scholar in the period, especially because the numismatic evidence-frequently reproduced, including in the Postel and Schickard books referred to by Barlow—seemed to support Jerome. (The numismatic evidence was in fact much more complex than was realised at the time. ${ }^{39}$ But this had some problematic consequences for biblical literalists of Barlow's stripe, because not only did it suggest that the surviving text of the Old Testament was not now read in the script in which it had been written, but also it was apparent that Samaritan, unlike Hebrew, used no vowel pointing. This might imply that the vowel pointing was a later and possibly non-divine invention. Barlow, a staunch Calvinist, was a theological conservative, and was compelled to reject the "Samaritan" interpretation out of hand.

Both the Lincoln and Queen's College copies of the Bibliotheca Apostolica Vaticana have thus passed through several pairs of notable hands between their times of publication and corporate accession. It is frustrating that the Chinese insert seen in Queen's by Hearne is now missing, and it would be satisfying if we could be exact about the transmission of the "Hungarian Runes" from Harsányi to Marshall to Mill. But the Queen's book may now be added to the number of books known to have been owned, and presumably read, by John Donne, whom we might hope marvelled at its augmented outlandish scripts; and the Lincoln volume provides some hitherto unnoticed evidence for English scholarly interest in the period in the pre-Latin Hungarian script, an interest we should associate with the burgeoning insular study of the northern and eastern European languages and their scripts. Over the Alps and across the sea, the Bibliotheca Apostolica Vaticana was put to uses responding to, but also transcending, its printed contents.

Works cited:

Manuscripts:

\footnotetext{
${ }^{37}$ Later in the book he also cross-references to another Bodleian copy of a book on scripts, namely Bonaventura Vulcanius, De literis \& lingua Getarum, sive Gothorum (Leiden, 1597), then at 8 o I 1 Art. It has subsequently moved. In this connection, Barlow can be seen at work in the Queen's Introductio in Chaldaicam linguam referred to above: on fp. 206v he rightly denies the genuineness of the "Gothic" alphabet there presented, countering with the evidence of the Junius/Marshall Gothic Gospels of 1665, which we encountered above. Barlow also added a cross-reference to the Bodleian's copy of Rocca's Bibliotheca itself to the title-page of the official interleaved copy of the 1620 Bodleian catalogue in his care (Bodleian, Lib. recs. d. 600).

${ }^{38}$ Barlow cites a rabbinical testimony from Schickard, Bechinath happeruschim, 82, 83.

39 Poole, "Barton's Coins," 388-90, with further references there.
} 
Oxford

Bodleian Library

MS Hearne's Diaries 21

Diary of Thomas Hearne

MS Marshall Or. 113

Diary of Thomas Marshall

MS Tanner 33

Papers of William Sancroft

MS Wood E 5

Papers of Anthony Wood

Annotated/provenanced books:

Oxford

Bodleian Library

4\% P 14 Art.Seld.

$4^{\circ}$ A 9 Jur.Seld.

Lib. recs. d. 600

Mar. 148 (14)

Lincoln College

B.2.9(1)

E. 9.2

Jacobus Colius's copy of Pansa

John Donne's copy of Arnisaeus

Librarian's copy of the James 1620 catalogue

Thomas Marshall's (?) copy of Tarczali

The Goes-Boxhorn-Marshall copy of Montagu

The Scaliger-Boxhorn-Marshall copy of Rocca

The Queen's College

JJ.s.174

Sel.c. 27

UU.b.1231(2)

UU.i.251

Z.e.126

Thomas Barlow's copy of Nadányi

John Donne's copy of Marcobruni

Thomas Barlow's copy of Tarczali

Thomas Barlow's copy of the Junius/Marshall Gothic/Old English Gospels

The Donne-Barlow copy of Rocca

Primary printed books:

Ambrogio, Teseo. Introductio ad Chaldaicam linguam, Syriacam, atque Armenicam, et decem alias linguas. Pavia: for the author, 1539.

Arnisaeus, Henningus. De subjectione et exemptione clericorum. Frankfurt: Johannes Thimius, 1612.

Bernard, Edward. De mensuris et ponderibus antiquis libri tres. $2^{\text {nd }}$ ed. Oxford: Sheldonian Theatre, 1688.

- - -, gen. ed. Catalogi Manuscriptorum Angliae et Hiberniae. Oxford: Sheldonian Theatre, 1697.

[Boxhorn, Marcus Zuerus]. Catalogus variorum \& insignium librorum, celeberrimi ac eruditissimi viri Marci Zueri Boxhornii, eloquentica ac historiarum, dum viveret, Professoris in alma Lugduno-Batav. Academia. Leiden: Petrus Leffen, 1654.

Brerewood, Edward. Enquiries touching the Diversity of Languages and Religions through the Cheife Parts of the World. London: John Bill, 1614.

de Bry, Theodore and Johann Israel. Alphabeta et Characteres. Frankfurt: de Bry, 1596.

Dernschwam, Hans. Tagebuch einer Reise nach Konstantinopel und Kleinasien (1553/55): Nach der Urschrift im Fugger-Archiv.

Ed. Franz Babinger. Munich: Duncker \& Humblot, 1923.

Donne, John. Devotions upon Emergent Occasions. London: Thomas Jones, 1624.

- - -. Essayes in Divinity. London: Richard Marriot, 1651.

Evelyn, John. Diary. Ed. E. S. de Beer. 6 vols. Oxford: Clarendon Press, 1955.

Fazello, Tommazo. De rebus Siculis decades duae. Palermo: Matthaeus Maida and Franciscus Carrara, 1558.

- - -. Rerum Sicularum scriptores ex recentioribus praecipui. Frankfurt: Andreas Wechel, 1579

Flatman, Thomas. Poems and Songs. $4^{\text {th }}$ ed. London: Benjamin Tooke, 1686.

Hearne, Thomas. Remarks and Collections of Thomas Hearne. 11 vols. Ed. by C. E. Doble et al. Oxford: OHS, 18851921.

Hickes, George, et al. Linguarum Vett. Septentrionalium Thesaurus. 3 vols. Oxford: Sheldonian Theatre, 1705.

Hyde, Thomas. "Epistola de mensuris et ponderibus Serum seu Sinensium." First edition appended to the second edition of Bernard, De mensuris. Second edition Epistola de mensuris et ponderibus Serum seu Sinensium. Oxford:

Sheldonian Theatre, 1688.

James, Thomas. Catalogus universalis librorum in Bibliotheca Bodleiana. Oxford: Bodleian, 1620.

Junius, Franciscus, and Thomas Marshall, eds. Quatuor D.N. Jesu Christi Euangeliorum versiones perantiqua dua, Gothica scil. et Anglo-Saxonica. Dort: Franciscus Junius, 1665.

Marcobruni, Paolo Emilio. Raccolta di lettere di diversi principi, \& altri signori. Venice: Pietro Dusinelli, 1595.

Marshall, Thomas. For my worthy freind Mr. Franciscus Junius: An Edition of the Correspondence of Francis Junius F.F. (15911677). Ed Sophie van Romburgh. Leiden: Brill, 2004.

Molnár Szenciensis, Albertus. Nova Grammatica Ungarica . . . libri duo. Hanover: Conrad Biermann, 1610. Facsimile: Bloomington: Indiana University, 1969.

Montagu, Richard. $\Theta \varepsilon \alpha \nu \theta \rho \omega \pi \iota \kappa o v$ seu De vita Jesu Christi Domini nostri originum ecclesiasticarum libri duo. London: Joshua Kirton and Thomas Warren, 1640. 
Nadányi, János. Florus Hungaricus. Amsterdam: Joannes à Waesberge, 1663.

Pansa, Mutio. Della Libraria vaticana ragionamenti. Rome: Giovanni Martinelli, 1590.

Postel, Guillaume. Linguarum duodecim characteribus differentium alphabetum, introductio, ac legendi modus. Paris: Dionysius Lescuier, 1538.

Plot, Robert. The Natural History of Oxford-Shire. Oxford: Sheldonian Theatre, 1677. $2^{\text {nd }}$ ed., Sheldonian Theatre, 1705.

Rocca, Angelo. Bibliotheca Apostolica Vaticana. Rome: Ex Typographia Apostolica Vaticana, 1591.

Scaliger, J. J. Epistolae. Leiden: Elzevier, 1627.

Schickard, Wilhelm. בחינת הפירושים Bechinath happeruschim, hoc est Examinis commentationum rabbinicarum in Mosen prodromus. Tübingen: the widow of Johan-Alexander Cellius, 1624.

Sudhoff, Karl. Bibliographia Paracelsica. Graz: Akademische Druck-U. Verlagsanstalt, 1958.

Tarczali, Pál. Brevis dissertatio de vocatione gentium et conversione Judaorum. Oxford: Leonard Lichfield, 1672.

Telegdi, Johannes. "Rudimenta priscae Hunnorum linguae.” [Manuscript originally 1598.] Ed. György Sebestyén, 1909. Available through: http://rudimenta.uw.hu/HU/thelegdi-forditasa.htm.

Thurneisser zum Thurn, Leonhard. מליצח xaì 'E $\rho \mu \eta v \varepsilon i ́ \alpha$ das ist ein Onomasticum und interpretatio. Berlin: Nikolaus Voltz, 1583.

- - -. Tabula quarundam syllabarum . . . / Tafel etliche Sylben . . Berlin: Nikolaus Voltz, 1583.

Vulcanius, Bonaventura. De literis \& lingua Getarum, sive Gothorum. Leiden: Franciscus Rapelengius, 1597.

Walton, Isaac. The Life of John Donne. London: Richard Marriot, 1658.

Wood, Anthony. Life and Times. Ed. Andrew Clark. 5 vols. Oxford: OHS, 1891-1900.

Secondary printed books and articles:

[Adcock, Alison]. The Spencers at Yarnton. [Oxford]: n.p., 1981.

Allgemeine Deutsche Biographie. Ed. Rochus, Freiherr von Liliencron et al. 56 vols. Leipzig: Duncker \& Humblot, $1875-$ 1912.

Alonso, Carlos. "Angelo Rocca, Polígrafo, bibliófilo y fundador de la biblioteca Angélica de Roma (1545-1620).”

Analecta Augustiniana 69 (2006): 9-32.

Babinger, Franz. "Eine neuentdeckte ungarische Kerbinschrift aus Konstantinapel vom Jahre 1515.” Ungarische

Rundschau 3 (1914): 41-52.

Bald, R. C. John Donne: A Life. $2^{\text {nd }}$ ed. Oxford: Clarendon Press, 1986.

Brüning, Volker Fritz. Bibliographie der alchemistischen Literatur, vol. 1. Munich: K. G. Saur, 2004.

Considine, John. Dictionaries in Early Modern Europe: Lexicography and the making of heritage. Cambridge: Cambridge

University Press, 2008.

Grafton, Anthony, ed. Rome Reborn: The Vatican Library and Renaissance Culture. Washington, DC: Library of Congress, 1993.

Hammond, Norman, and Wang Xiao-Hui. “Sir Thomas Spencer's Chinese Seal.” Antiquity 72 (1998): 550-53.

Kármán, Gábor. A Seventeenth-Century Odyssey in East Central Europe: The Life of Jakab Harsányi Nagy. Leiden: Brill, 2015.

Keynes, Geoffrey. A Bibliography of Dr. John Donne, Dean of St Paul's. $4^{\text {th }}$ ed. Oxford: Clarendon Press, 1973.

Madan, Falconer. Oxford Books, 3 vols. Oxford: Clarendon Press, 1895-1931. Cited by number.

Magrath, J. R. The Queen's College. 2 vols. Oxford: Clarendon Press, 1921.

Nelles, Paul. "The Vatican Library Alphabets, Luca Orfei, and Graphic Media in Sistine Rome." In For the Sake of

Learning: Essays in Honour of Anthony Grafton. Ed. Ann Balir and Anja-Silvia Goeing. Leiden: Brill, 2016. Pp. $441-68$.

Nixon, Howard. Broxbourne Library: Styles and designs of bookbindings, from the twelfth to the twentieth century. London: Broxbourne Library, 1956.

Poole, William. “A Late Sixteenth-Century Cryptographical Treatise: Jacobus Colius's 'Tractatus de fictis characteribus' (1584-6).” Journal of the Warburg and Courtauld Institutes 64 (2011): 213-39.

- - . "The Letters of Shen Fuzong to Thomas Hyde, 1687-88." electronic British Library Journal (2015), article 9.

- - -. "Barlow's Books: Prolegomena for the study of the library of Thomas Barlow (1608/9-91)." Bodleian Library Record 30 (2017): 13-46.

- - -. "Barton's Coins: Eighteenth-Century Numismatics in New College, Oxford." Journal of the History of Collections 30 (2018): 385-93.

Serrai, Alfredo, et al. Storia della bibliografia. 11 vols. in 13. Rome: Bulzoni, 1988-2001.

- - . Angelo Rocca, fondatore della prima biblioteca pubblica europea: nel quarto centenario della Biblioteca angelica. Milan: Sylvestre Bonnard, 2004.

Spitzer, Gabriele. —und die Spree fübrt Gold: Leonhard Thurneysser zum Thurn: Astrologe, Alchimist, Aræt und Drucker im Berlin des 16. Jahrbunderts. Berlin: Staatsbibliothek zu Berlin, Preussischer Kulturbesitz, 1996. 